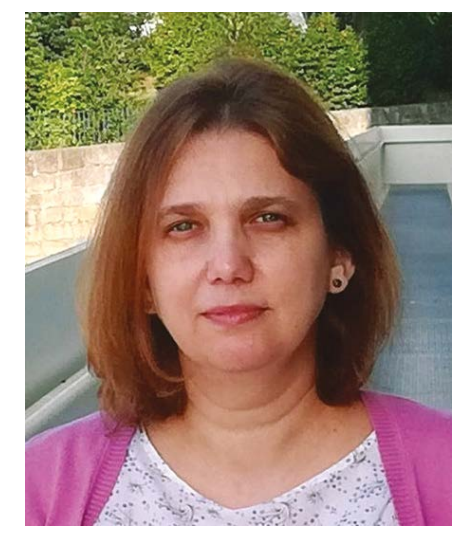

\section{Marcela Segundo Destacada pelo seu Papel de Liderança em Química Analítica}

Marcela Segundo, Professora Auxiliar da Faculdade de Farmácia da Universidade do Porto (FFUP) e investigadora do LAQV/REQUIMTE, integra o grupo de cerca de 60 cientistas destacadas pela revista Analytical and Bioanalytical Chemistry, uma publicação da editora Springer Nature, através da publicação de um número especial (springer.com/journal/216/ volumes-and-issues/412-24).

A distinção de Female Role Model in Analytical Chemistry visou a celebração do papel da mulher na liderança de investigação na área da Química Analítica.

Marcela Segundo fez parte da Direção da Sociedade Portuguesa de Química entre 2010 e 2013 e foi Presidente da Divisão de Química Analítica entre 2016 e 2018. Desde 2018 que é Secretária da Divisão de Química Analítica da European Chemical Society, EuChems.

$>$

Bruno Machado

brunofm@fe.up.pt

\title{
Prémio EuChemS Lecture 2019 Atribuído a David Portehault
}

O Prémio EuChemS Lecture 2019 foi concedido a David Portehault. Todos os anos são premiados os principais resultados atingidos por um cientista júnior que trabalha no campo da Química num país com uma organização pertencente à EuChemS. Normalmente, o vencedor tem a oportunidade de dar uma palestra no próximo EuChems Chemistry Congress ou numa conferência de Divisão Científica da EuChems (Professional Networks, PN). Porém, devido à pandemia COVID-19 e ao adiamento do $8^{\text {th }}$ EuChems Chemistry Congress (ECC8) para 2022, o evento será realizado online em 2021.

Na sua palestra, David Portehault irá apresentar os resultados recentes do seu grupo para a síntese de nanomateriais originais, baseados em condições geológicas observadas na Natureza. Ele irá mostrar vários exemplos de nanomateriais inorgânicos, discutir os seus mecanismos de formação, e ilustrar as propriedades eletrocrómicas e eletrocatalíticas demonstradas por nanopartículas destes materiais.

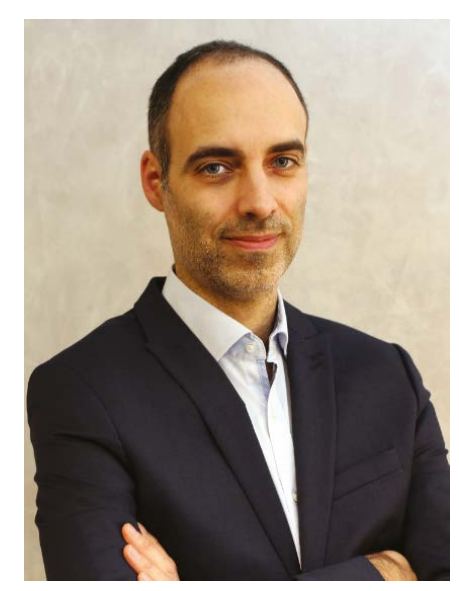

$>$

Bruno Machado

brunofm@fe.up.pt 